\title{
For Feminist Narratology
}

\author{
Susan Knutson
}

Narratology, the structuralist analysis of narrative, ${ }^{1}$ can specify in formal terms the ideological commitment, conscious or not, of a narrative text. Feminist narratology can identify gender-determined forms in traditional narrative and analyze feminist revision of narrative grammar. Ultimately, feminist narratology may help correct the ethnocentrism of narratology itself by clarifying that a certain dominant sense of story is culturally determined.

Every feminist knows that too many stories end with fantasy marriages or with barely concealed threats directed at women. The latter type of story features fascinating, transgressive women: Guenevere, whose love brought down Camelot; Eve, whose curiosity exiled 'man' from Paradise; or Clytemnestra, who murdered her husband to revenge their daughter, and whose Furies hounded her son and murderer until the other Gods intervened. Their's are the stories of Camelot, of 'man's' fall from grace, and of the founding of the Athenian City State. Yet each heroic female figure has been rewritten; from a subject who dared to act, she has become an obstacle to the stability of a patriarchal institution. In narratological terms, these actors have changed actantial function. The shift in narrative form encodes a basic patriarchal message: the human subject is generically male.

Narratology describes a narrative grammar used to produce an infinite number of narratives. 'Parts of speech,' tense, voice, and mood characterize the narrative utterance. Three pairs of actantial functions, subject / object, helper / obstacle, and power / receiver, correspond to the grammatical subject / object, modifiers and indirect object. A subject has an aim or object, and is helped by helpers and opposed by obstacles. The subject's success or failure depends on his or her power, and someone or something benefits at the end. The narrative sentence built on these principles is the quest, and the quest, at its most abstract, has been proposed as a universal narrative grammar. There are two 
major problems with accepting this proposition. First, woman's position in quest grammar, even at its most abstract, is well-defined and reproduces patriarchal gender. Second, the grammar itself is based on the binary opposition of hero and obstacle. Subordinating everything to the desire of the subject, it is inherently monologic, teleological, and implicated with patriarchal gender. Quest grammar depends on and reproduces hierarchical power relations based on binary oppositions which are not universal, but are characteristic of Indo-European cultures.

Narrative fabula has been analyzed by the Soviet semiotician, Jurij Lotman, who identifies inside and outside as the primordial narrative opposition, and birth as a kind of arché-story. ${ }^{2}$ Teresa de Lauretis draws the necessary conclusions with respect to gender, arguing that in western culture the narrative hero is generically male and the obstacles or matrix he encounters and crosses are generically female. ${ }^{3}$ Thus narrative structure at its most abstract is a cultural producer of gender.Clytemnestra's displacement as hero of her own story aligned her with the appropriate plot position for a woman. As hero, she would be the subject of an unsuccessful and 'unladylike' quest for revenge.

In the canon of tales of transgressive women, that of Clytemnestra preserves the memory of a critical historical shift, and it could be argued that the story surpasses the Oedipus myth as a theory of gender, law and culture. Clytemnestra's story features a transgressive female subject who becomes an obstacle. Her story transmits threatening messages to other women. It celebrates the foundation of the patriarchal state, and specifies the principle 'father-right over mother-right.' It demonstrates patriarchal overwriting as well as the usefulness of feminist narratology.

The elements of her fabula are as follows: she was conceived, along with Helen of Troy, when Zeus took the form of a swan to rape Leda. Clytemnestra was mortal. She married Agamemnon, King of Mycenae, and bore three children, Iphegenia, Orestes, and Electra. The Trojan War began and Agamemnon, setting out to aid his brother, sacrificed Iphegenia to obtain favourable winds. He was gone for ten years, during which time Clytemnestra took Aegesthius as a lover. She and Aegesthius murdered Agamemnon when he returned from Troy. Orestes and Electra murdered them, in revenge. Orestes was hounded by the Furies for having killed his mother. Apollo intervened on 
Orestes' behalf, Athene cast a deciding vote in favour of the father, and the Furies were reconciled to a system of patriarchal justice embodied in the secular, Athenian state which, from this point on, took precedence over older, blood-related law.

The first step in structuralist analysis is to distinguish between the narrative content (fabula) and the form in which the narrative is told (story, text). The fabula is the series of events caused or experienced by an actor: the elements just related. The story is a version of these events. Homer's version of these events scarcely mentions Clytemnestra. In Aeschylus' dramatic trilogy, performed in Athens in the 5 th century B.C.,Orestes is the subject of the narrative sentence and a founding hero of Athens (along with Theseus, who defeated the Amazons). A modern, feminist version, however, might celebrate Clytemnestra's greatness and mourn her fall. ${ }^{4}$ As fabula subject, Clytemnestra experiences a change of condition: a powerful queen descended from the gods becomes a harmless ghost. Like Oedipus, she inscribes a tragic praxis: hers begins with her decision to revenge her daughter, and ends with the establishment of the patriarchal state. Her story is a paradigmatic feminist tragedy, but was early rewritten with Orestes as fabula subject. Thus, the same events can be arranged and elaborated into different fabulas and different stories, and such rearrangement is a social action.

Gender / power relations are encoded in narrative form, and at the three levels of fabula, story, and text, feminist narratology can break the code. A female obstacle, at the level of fabula, frequently signifies patriarchal overwriting. A male subject with a female object and / or obstacle always indicates conformity with patriarchal gender, and may also mark the erasure of a female hero. At the story level, events are focussed through an external focalizer or a character-focalizer who experiences the events of the fabula. Who is sensing, seeing, hearing and interpreting? Based on what body of knowledge? Is there a woman's body in this story? Finally, at the level of text or words, a narrative agent can comment, argue, describe or renderironic. How is the power of the narrator represented or used? Who is speaking to whom, and what kind of world is created in the process? Would a woman be comfortable in this world? Or is a male narrator relying on the power of the masculine generic to naturalize the fact that a man is speaking to other men in a world where women areobjects or obstacles? The masculinegeneric (white / able-bodied / male= unmarked) operates insid- 


\section{For Feminist Narratology $\cdot 13$}

iously at all levels of language to sustain the system of binary oppositions of which it is a part.

Canadian feminist writing exemplifies a double strategy which contests binary gender definition in narrative while reclaiming the hero / subject position for women. Binary resolution is undermined through nominative, repetitive forms which are open-ended and spiralling rather than linear. At the same time, women are heroes of their own stories. These strategies are used by Lillian Allen in Revolutionary Tea Party, by Nicole Brossard in Picture Theory, and by Daphne Marlatt in How Hug a Stone. Daphne Marlatt also writes in a kind of grammatical 'middle voice' which mediates opposition between noun and verb. Feminist writers have noted that the patriarchal hero is a singular, lonesome hero. Collective transformation is a feature of fabula in the feminine. ${ }^{5}$ Stories are focalized by characters who draw on what women have collectively learned. At the level of language, women speak to each other.

Feminist narratology makes it possible to systematize what is meant by narrative 'in the feminine.' In the future, it may help to free narratology from the blinkers of European ethnocentrism, which constitute a barrier to further research. The Indo-European canon of stories, and narratology itself, are implicated in the structuring system of binary oppositions. Many North American Indian languages are less indebted to the opposition between noun and verb; what does this imply for the hero / obstacle opposition in narrative? What would a 'universal' narrative grammar be for a culture not committed to binary resolutions? As the 'universal man' topples, a plurality of voices fills our world, and structuralist analysis of narrative, combined with feminist consciousness, may help us to understand what we are hearing and saying to each other.

\section{Notes}

1. See Mieke Bal, Narratology: Introduction to the Theory of Narrative, trans. Christine van Boheemen (Toronto: Toronto U.P.,1985).

2. Jurij Lotman, 'The Origin of Plot in the Light of Topology,' Poetics Today, Vol. 1,No. 1-2 (1979), pp. 161-184.

3. Teresa de Lauretis, Alice Doesn't: Feminism, Semiotics, Cinema (Bloomington: Indiana U.P., 1984), pp. 103-157.

4. I imagine Clytemnestra's tragedy written in the spirit of Monique Wittig's Le corps lesbien (Paris: Minuit, 1973). 


\section{Tessera}

5. 'In the feminine' translates the Québécois formula 'au féminin.' See Nicole Brossard, 'De radical à intégrales,' La lettre aérienne (Montréal:

Remue-ménage, 1985), 87-106; trans. Marlene Wildeman, 'From Radical to Integral,' The Aerial Letter (Toronto: The Women's Press, 1988); L'Emergence d'une culture au féminin, sous la direction de Marisa Zavalloni (Montréal: Les Editions Saint-Martin, 1987); in the feminine: women and words / les femmes et les mots: conference proceedings, 1983, eds. Anne Dybikowski et al. (Edmonton: Longspoon, 1983). 